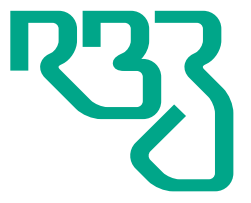

Revista

Brasileira de

Zootecnia

Brazilian Journal of Animal Science

ISSN 1806-9290

www.rbz.org.br

\section{Additional feeding during late gestation improves initial litter weight of lactating sows exposed to high ambient temperature}

\author{
Yo Han Choi ${ }^{1}$, Abdolreza Hosseindoust ${ }^{2}$, Min Ju Kim², Kwang Yeol Kim², Jun \\ Hyung Lee ${ }^{2}$, Young Hwa Kim ${ }^{1}$, Jin Soo Kim², Byung Jo Chae ${ }^{2^{*}}$ (iD \\ ${ }^{1}$ Department of Animal Resources Development Swine Science Division, RDA, Cheonan-si, \\ Chungnam, Republic of Korea. \\ ${ }^{2}$ Kangwon National University, College of Animal Life Sciences, Department of Animal \\ Resources Science, Chuncheon, Republic of Korea.
}

*Corresponding author:

bjchae@kangwon.ac.kr

Received: February 20, 2018

Accepted: April 10, 2019

How to cite: Choi, Y. H.; Hosseindoust, A.; Kim,

M. J.; Kim, K. Y.; Lee, J. H.; Kim, Y. H.; Kim, J. S.

and Chae, B. J. 2019. Additional feeding during

late gestation improves initial litter weight

of lactating sows exposed to high ambient

temperature. Revista Brasileira de Zootecnia 48:e20180028.

https://doi.org/10.1590/rbz4820180028

Copyright: This is an open access article distributed under the terms of the

Creative Commons Attribution License

(http://creativecommons.org/licenses/by/4.0/), which permits unrestricted use, distribution, and reproduction in any medium, provided the original work is properly cited.

\begin{abstract}
The present study investigated the impacts of additional feeding (AF; containing $16 \%$ excess feed than control diet in the last two weeks of gestation) during late gestation period and different backfat thickness (BFT) including low $(<20 \mathrm{~mm})$ and high ( $\geq 20 \mathrm{~mm}$ ) backfat on reproductive performance, litter size, blood metabolites, hormonal profiles, colostrum, and milk composition of sows from day 90 of gestation to farrowing, and from farrowing to weaning during summer (average $28.3^{\circ} \mathrm{C}$ ). Fiftyfour crossbred sows (Yorkshire $\times$ Landrace) were allotted to one of four treatments according to a $2 \times 2$ factorial arrangement. There was no $\mathrm{AF} \times \mathrm{BFT}$ interaction for any of the measured variables. The body weight change of sows was decreased for $<20 \mathrm{~mm}$ in $\mathrm{BFT}$ and $\mathrm{AF}$ treatments during late gestation and farrowing to weaning periods. The BFT change of sows was higher in AF during late gestation and higher in $\geq 20 \mathrm{~mm} B F T$ during late gestation and farrowing to weaning periods. There were no effects of AF and BFT on the average daily feed intake and weaning-to-oestrus interval; however, sows in AF groups had a greater litter uniformity at birth and initial litter weight. Hormone profiles, colostrum, and milk composition of sows were not different among the treatments. Additional feeding during the last two weeks of gestation increases initial litter size in summer; however, final litter weight is not affected.
\end{abstract}

Keywords: backfat thickness, gestating sows, heat stress, reproductive traits

\title{
Introduction
}

The reproductive performance and release of the reproductive hormone in sows are greatly influenced by nutrient intake during gestation (Ren et al., 2017a). A restricted feeding strategy during gestation does not always facilitate the recovery of body reserves, particularly in heat-stressed sows, due to their higher metabolic energy requirements. Increasing the average daily feed intake (ADFI) during late gestation helps with mammary gland development and milk production (Weldon et al., 1991), as well as foetal growth (Dwyer et al., 1994; Cerisuelo et al., 2009). Moreover, Dwyer et al. (1994) observed that extra feeding during gestation increases the uniformity of foetal growth, reducing the distribution of piglet body weight (BW) at farrowing. Uniformity in weight of newborn piglets seems crucial, because the drop in milk production during the warm season leads to more competition between piglets, which may seriously increase the likelihood of smaller and more susceptible piglets being culled. Therefore, smaller piglets would be unable to receive adequate milk in a competitive environment due to insufficient milk production in heat-stressed conditions. 
The total body reserves of sows are reflected by backfat thickness (BFT) and can be used to check whether feeding strategies are optimal for reproductive performance. The negative effects of heat stress (HS) on body reserves and ADFI may be different in sows with different BFT. It has been reported that the excessive loss of body protein and BFT during late gestation correlates with a greater percentage of stillborn piglets (Maes et al., 2004), reduced litter size, litter growth (McKay, 1993), and prolonged weaning-to-oestrus interval (De Rensis et al., 2005). However, a greater culling degree, due to mobility issues, occurs at the end of gestation because of excess body fat (Dourmad et al., 2001). Therefore, the effect of increasing the ADFI in gestating sows with different amounts of BFT to manipulate the initial litter weight remains uncertain. A balance between ADFI and the optimal range of BFT for sows during gestation should be maintained to ensure the best reproductive performance. In this context, the objective of this experiment was to test our hypothesis that additional ADFI during late gestation influences the reproductive and litter performance of sows with lower body reserves in high ambient temperature.

\section{Material and Methods}

The project underwent proper ethical standards and the experiments (KW-170519-1) were approved by the local Institutional Animal Care and Use Committee in Chuncheon, Republic of Korea.

Fifty-four crossbred sows (Yorkshire × Landrace; average initial BW, $221.7 \pm 16.3 \mathrm{~kg} ; 14$ in second parity, 17 in third parity, 13 in forth parity, and 10 in fifth parity) were allotted to one of four treatments according to a $2 \times 2$ factorial arrangement of treatments. All sows used in the present study were artificially inseminated two times after the onset of oestrus, and pregnancy was detected and confirmed at day 30 post-breeding using an Pharvision B-mode ultrasound machine (AV 2100V; Ambisea Tech. Corp., Shenzhen, China). Sow BFT at the 10 th rib, $6.5 \mathrm{~cm}$ from one side of the backbone, was measured at day 90 , farrowing, and weaning (day 25 of lactation) by using a medical imaging ultrasound (Loveland, CO; USA). Changes in BFT of sows during lactation were measured by calculating the difference between BFT at day 1 of lactation and BFT at weaning (day 25 of lactation). Standard litter traits such as total number born and born alive, BW $(\mathrm{kg})$ at birth and weaning, growth rate $(\mathrm{kg} / \mathrm{d})$, and average daily gain (g/piglets) were recorded individually. Feed intake $(\mathrm{kg} / \mathrm{d})$ of each sow and weaning-to-oestrus interval (days) were also recorded. All sows were fed a common diet according to the NRC (2012) requirements for gestation and lactation and $2.4 \mathrm{~kg}$ regular gestation diet with $16 \%$ additional feed $(2.8 \mathrm{~kg})$ during the last two weeks of the gestation period. Cross-fostering was performed within one day of parturition and occurred only among sows of the same treatment. From one day after weaning, oestrus detection was performed twice daily ( 08.00 and $16.30 \mathrm{~h}$ ) for $10 \mathrm{~min}$ by boar exposure.

This study was carried out from 29 June to 27 August 2016 (during the summer season in South Korea). The daily rectal temperature was recorded at 15:00 $\mathrm{h}$ during the study. The minimum, average, and maximum ambient temperatures observed in the conventional farrowing rooms were $25.4 \pm 1.3$, $28.3 \pm 1.5$, and $30.6 \pm 2.1^{\circ} \mathrm{C}$, respectively.

On day 1 (post farrowing) and day 25 (weaning, after piglet removal) of lactation, 10-mL blood samples were collected by ear vein catheter from eight randomly selected sows per treatment before the morning feeding at $6.00 \mathrm{~h}$ using a disposable vacutainer tube containing sodium heparin as anticoagulant (Becton Dickinson, Franklin, N)). A serum automatic biochemical analyser (Fuji Dri-chem $3500 \mathrm{i}$, Japan) was used to measure concentrations of blood urea nitrogen, glucose, and triglyceride. After centrifugation $(3,000 \times \mathrm{g}$ for $20 \mathrm{~min})$, plasma samples were separated and stored at $-20^{\circ} \mathrm{C}$ and later analysed for blood parameters.

On day 1 (post farrowing) and day 25 (weaning, after piglet removal) of lactation, 10-mL blood samples were collected by ear vein catheter from eight randomly selected sows per treatment before feeding (before $09.00 \mathrm{~h}$ ) at 60 -min intervals for $4 \mathrm{~h}$ from 09.00 to $13.00 \mathrm{~h}$ for analysis of insulin, and one blood sample was collected before the morning feeding at $06.00 \mathrm{~h}$ for follicle stimulating hormone (FSH), luteinizing hormone (LH), and cortisol analyses. Swine insulin, cortisol, LH, and FSH kits (Endocrine Technologies Inc., USA) were used, and their concentrations were determined in duplicate by ELISA 
using Biolog MicroStation system. Intra- and interassay CV for insulin, LH, and FSH were 2.43 and $12.32,7.65$ and 15.91, and 4.71 and $16.86 \%$, respectively. The minimal detectable concentrations of insulin, $\mathrm{LH}$ and FSH were $0.5,0.1$, and $0.5 \mathrm{ng} / \mathrm{mL}$, respectively.

Colostrum and milk were collected $(30 \mathrm{~mL})$ just after the birth of the first piglet and 10 days after farrowing, respectively. The samples were analysed for protein, fat, and lactose composition. Nutritional composition (fat, protein, and lactose content) was estimated a milk analyser Milko-Scan 133B (Type 10911) within $24 \mathrm{~h}$. Content of IgG (mg/mL) was measured by pig IgG ELISA Kit (E101-104, Bethyl Lab., TX, USA).

Data generated in the present experiment were analysed as a $2 \times 2$ factorial arrangement in a completely randomised design. Additional feeding (AF) and BFT were the fixed effect and sow was considered as the experimental unit. The main effects of AF, BFT at day 90 to farrowing and from farrowing to weaning, and their interaction were determined by the mixed procedure of SAS program (Statistical Analysis System, version 9.2). P-values $\leq 0.05$ were considered statistically significant. The data were tested for main effects of AF, BFT, and their possible interactions. The following model statement was used:

$$
Y i j t=\mu+\alpha i+\beta j+\alpha \beta i j+\varepsilon i j t,
$$

in which Yijt $=$ measured response, $\mu=$ overall mean, $\alpha \mathrm{i}=\mathrm{AF}, \beta \mathrm{j}=\mathrm{BFT}$ effect, $\alpha \beta \mathrm{ij}=$ interaction between $\mathrm{AF}$ and $\mathrm{BFT}$ effect, and $\varepsilon \mathrm{ijt}=$ residual error.

\section{Results}

There was no difference in rectal temperature of sows between the treatments (data not shown), and the average rectal temperatures were 38.9 and $39.4{ }^{\circ} \mathrm{C}$ in gestation and lactation periods, respectively. There was no AF×BFT interaction for any of the measured parameters (Table 1). Body weight of sows was not different among the treatments. However, sows in AF and low backfat (LB; $<20 \mathrm{~mm}$ ) groups had significantly lower $(\mathrm{P}<0.05) \mathrm{BW}$ changes during day 109 to weaning. The BFT of sows were increased in

Table 1 - Effects of additional feeding (AF) on reproductive performance of gestating sows during summer

\begin{tabular}{|c|c|c|c|c|c|c|c|c|}
\hline \multirow{2}{*}{$\begin{array}{l}\text { Additional feeding } \\
\text { Backfat thickness (BFT) }\end{array}$} & \multicolumn{2}{|c|}{ Control } & \multicolumn{2}{|c|}{$\mathrm{AF}$} & \multirow[b]{2}{*}{ SEM $^{1}$} & \multicolumn{3}{|c|}{ P-value } \\
\hline & $\begin{array}{c}\text { LB } \\
(n=12)\end{array}$ & $\begin{array}{c}\text { HB } \\
(n=15)\end{array}$ & $\begin{array}{c}\text { LB } \\
(n=13)\end{array}$ & $\begin{array}{c}\text { HB } \\
(n=14)\end{array}$ & & $\mathrm{AF}$ & $\mathrm{BFT}$ & $\mathrm{AF} \times \mathrm{BFT}$ \\
\hline Parity & 3.25 & 3.47 & 3.31 & 3.64 & 0.31 & 0.719 & 0.397 & 0.855 \\
\hline \multicolumn{9}{|l|}{ Sow body weight (kg) } \\
\hline Gestation (day 90) & 214.8 & 223.6 & 220.4 & 226.4 & 4.28 & 0.354 & 0.103 & 0.748 \\
\hline Gestation (day 109) & 219.5 & 229.8 & 225.9 & 233.6 & 4.81 & 0.312 & 0.076 & 0.793 \\
\hline Weaning & 197.6 & 204.7 & 206.3 & 210.5 & 4.16 & 0.096 & 0.190 & 0.745 \\
\hline \multicolumn{9}{|l|}{ Change } \\
\hline Day 90 to 109 & 4.65 & 6.18 & 5.46 & 7.24 & 0.85 & 0.281 & 0.059 & 0.888 \\
\hline 109 days to weaning & 21.92 & 25.15 & 19.64 & 23.06 & 0.96 & 0.035 & $<0.01$ & 0.928 \\
\hline \multicolumn{9}{|l|}{ Sow backfat thickness (mm) } \\
\hline Gestation (day 90) & 19.46 & 21.70 & 19.54 & 21.61 & 0.22 & 0.978 & $<0.01$ & 0.708 \\
\hline Gestation (day 109) & 20.29 & 23.10 & 20.77 & 23.64 & 0.22 & 0.030 & $<0.01$ & 0.887 \\
\hline Weaning & 16.13 & 18.13 & 16.88 & 19.11 & 0.25 & $<0.01$ & $<0.01$ & 0.691 \\
\hline \multicolumn{9}{|l|}{ Change } \\
\hline Day 90 to 109 & 0.83 & 1.40 & 1.23 & 2.04 & 0.14 & $<0.01$ & $<0.01$ & 0.419 \\
\hline 109 days to weaning & 4.17 & 4.97 & 3.88 & 4.54 & 0.27 & 0.187 & $<0.01$ & 0.781 \\
\hline \multicolumn{9}{|l|}{ Daily feed intake (kg/d) } \\
\hline Lactation & 5.28 & 4.99 & 5.38 & 5.21 & 0.14 & 0.249 & 0.097 & 0.684 \\
\hline $\begin{array}{l}\text { Weaning to oestrus interval } \\
\text { (days) }\end{array}$ & 5.25 & 5.07 & 5.08 & 4.86 & 0.21 & 0.384 & 0.359 & 0.934 \\
\hline
\end{tabular}

LB (<20 mm) - low backfat; HB ( $\geq 20 \mathrm{~mm})$ - high backfat.

SEM - standard error of the mean. 
$\mathrm{AF}$ and high backfat $(\mathrm{HB} ; \geq 20 \mathrm{~mm})$ groups at farrowing and weaning $(\mathrm{P}<0.05)$. Changes in BFT during gestation (from day 90 to 109) were greater $(\mathrm{P}<0.05)$ in $\mathrm{AF}$ and HB groups; however, $\mathrm{AF}$ did not affect $B F T$ change $(\mathrm{P}>0.05)$ during day 109 to weaning. The AF and BFT showed no effects $(\mathrm{P}>0.05)$ on ADFI and weaning-to-oestrus interval in sows from day 90 to weaning; however, ADFI of sows in HB group tended to decrease compared with that of sows in LB group.

There was no $\mathrm{AF} \times \mathrm{BFT}$ interaction for any of the measured variables. There were no significant effects $(\mathrm{P}>0.05)$ of $\mathrm{AF}$ and $\mathrm{BFT}$ on litter size, number of weaned piglets, survival rate, and average daily gain (Table 2). However, AF significantly improved $(\mathrm{P}<0.05)$ initial litter weight of piglets. The coefficient of variation of birth weight of piglets was improved in $\mathrm{AF}$ treatment.

There were no significant effects $(\mathrm{P}>0.05)$ and interaction between AF and BFT on blood urea nitrogen, glucose, triglyceride, and creatinine level of weaning and post-farrowing sows during the summer season (Table 3).

Table 2 - Effects of additional feeding (AF) and backfat thickness (BFT) on litter size and piglet performance of sows during summer

\begin{tabular}{|c|c|c|c|c|c|c|c|c|}
\hline \multirow{2}{*}{$\begin{array}{l}\text { Additional feeding } \\
\text { Backfat thickness }\end{array}$} & \multicolumn{2}{|c|}{ Control } & \multicolumn{2}{|c|}{$\mathrm{AF}$} & \multirow[b]{2}{*}{ SEM } & \multicolumn{3}{|c|}{ P-value } \\
\hline & $\begin{array}{c}\text { LB } \\
(n=12)\end{array}$ & $\begin{array}{c}\text { HB } \\
(n=15)\end{array}$ & $\begin{array}{c}\text { LB } \\
(n=13)\end{array}$ & $\begin{array}{c}\text { HB } \\
(n=14)\end{array}$ & & $\mathrm{AF}$ & $\mathrm{BFT}$ & $\mathrm{AF} \times \mathrm{BFT}$ \\
\hline \multicolumn{9}{|l|}{ Litter size } \\
\hline Initial litter size & 10.2 & 10.3 & 10.1 & 10.2 & 0.33 & 0.829 & 0.719 & 0.955 \\
\hline Piglets weaned & 9.83 & 9.93 & 9.85 & 9.86 & 0.31 & 0.919 & 0.858 & 0.886 \\
\hline Survival rate (\%) & 96.9 & 96.8 & 98.0 & 96.6 & 1.37 & 0.765 & 0.586 & 0.640 \\
\hline CV birth weight (\%) & 23.9 & 21.7 & 20.3 & 20.8 & 0.93 & 0.045 & 0.891 & 0.119 \\
\hline \multicolumn{9}{|l|}{ Litter weight (kg) } \\
\hline Initial litter weight/sow & 13.19 & 13.18 & 14.18 & 14.13 & 0.36 & 0.011 & 0.930 & 0.960 \\
\hline Litter weight/piglet/sow & 1.33 & 1.30 & 1.43 & 1.39 & 0.06 & 0.083 & 0.536 & 0.933 \\
\hline Weaning weight/litter/sow & 67.8 & 69.7 & 70.1 & 71.2 & 1.93 & 0.338 & 0.446 & 0.815 \\
\hline Weaning weight/piglet/sow & 6.96 & 7.03 & 7.13 & 7.22 & 0.10 & 0.088 & 0.442 & 0.954 \\
\hline Total weight gain/litter & 54.6 & 56.6 & 55.9 & 57.0 & 1.90 & 0.640 & 0.430 & 0.820 \\
\hline Average daily gain (g/piglet) & 223.6 & 227.8 & 226.8 & 231.1 & 3.67 & 0.380 & 0.250 & 0.993 \\
\hline
\end{tabular}

LB ( $<20 \mathrm{~mm})$ - low backfat; HB ( $\geq 20 \mathrm{~mm})$ - high backfat.

CV - coefficient of variation; SEM - standard error of mean.

Table 3 - Effects of additional feeding (AF) and backfat thickness (BFT) on blood metabolites of sows during summer

\begin{tabular}{|c|c|c|c|c|c|c|c|c|}
\hline \multirow{2}{*}{$\begin{array}{l}\text { Additional feeding } \\
\text { Backfat thickness }\end{array}$} & \multicolumn{2}{|c|}{ Control } & \multicolumn{2}{|c|}{$\mathrm{AF}$} & \multirow[b]{2}{*}{ SEM } & \multicolumn{3}{|c|}{ P-value } \\
\hline & $\begin{array}{c}\text { LB } \\
(n=12)\end{array}$ & $\begin{array}{c}\text { HB } \\
(n=15)\end{array}$ & $\begin{array}{c}\text { LB } \\
(n=13)\end{array}$ & $\begin{array}{c}\text { HB } \\
(n=14)\end{array}$ & & $\mathrm{AF}$ & $\mathrm{BFT}$ & $\mathrm{AF} \times \mathrm{BFT}$ \\
\hline \multicolumn{9}{|l|}{ Post farrowing $\left(\mathrm{mg} \mathrm{dL}^{-1}\right)$} \\
\hline Blood urea nitrogen & 17.75 & 17.35 & 17.37 & 17.10 & 0.57 & 0.707 & 0.689 & 0.938 \\
\hline Glucose & 91.20 & 92.35 & 91.74 & 92.95 & 1.48 & 0.790 & 0.583 & 0.988 \\
\hline Triglyceride & 57.36 & 55.87 & 57.21 & 56.45 & 0.63 & 0.813 & 0.216 & 0.691 \\
\hline Creatinine & 2.26 & 2.21 & 2.24 & 2.18 & 0.09 & 0.838 & 0.647 & 0.998 \\
\hline \multicolumn{9}{|l|}{ Weaning $\left(\mathrm{mg} \mathrm{dL}^{-1}\right)$} \\
\hline Blood urea nitrogen & 18.55 & 18.39 & 18.63 & 18.83 & 0.71 & 0.803 & 0.980 & 0.863 \\
\hline Glucose & 90.55 & 91.07 & 91.13 & 91.26 & 1.77 & 0.883 & 0.898 & 0.941 \\
\hline Triglyceride & 28.45 & 27.70 & 27.88 & 26.68 & 0.75 & 0.462 & 0.367 & 0.835 \\
\hline Creatinine & 1.67 & 1.63 & 1.69 & 1.62 & 0.08 & 0.958 & 0.674 & 0.921 \\
\hline
\end{tabular}

LB $(<20 \mathrm{~mm})$ - low backfat; HB $(\geq 20 \mathrm{~mm})$ - high backfat.

SEM - standard error of mean. 
There were no effects $(\mathrm{P}>0.05)$ on FSH and LH of weaning and post-farrowing sows (Table 4). In addition, there was no interaction $(\mathrm{P}>0.05)$ between $\mathrm{AF}$ and BFT on insulin level of gestation on day 90 , post-farrowing, and weaning sows during the summer season.

There was no AF×BFT interaction for any of the measured variables (Table 5). Additional feeding and BFT had no significant effects $(\mathrm{P}>0.05)$ on colostrum and milk composition of sows during the summer season.

\section{Discussion}

In this study, the minimum, average, and maximum daily ambient temperature were $25.4 \pm 1.3,28.3 \pm 1.5$, and $30.6 \pm 2.1^{\circ} \mathrm{C}$, respectively. These temperatures were within the range generally expected to induce HS in gestating and lactating sows since the average rectal temperature of sows in this study were

Table 4 - Effects of additional feeding (AF) and backfat thickness (BFT) on hormone profiles of sows during summer

\begin{tabular}{|c|c|c|c|c|c|c|c|c|}
\hline \multirow{2}{*}{$\begin{array}{l}\text { Additional feeding } \\
\text { Backfat thickness }\end{array}$} & \multicolumn{2}{|c|}{ Control } & \multicolumn{2}{|c|}{$\mathrm{AF}$} & \multirow[b]{2}{*}{ SEM } & \multicolumn{3}{|c|}{ P-value } \\
\hline & $\begin{array}{c}\text { LB } \\
(\mathrm{n}=12)\end{array}$ & $\begin{array}{c}\text { HB } \\
(n=15)\end{array}$ & $\begin{array}{c}\text { LB } \\
(n=13)\end{array}$ & $\begin{array}{c}\mathrm{HB} \\
(\mathrm{n}=14)\end{array}$ & & $\mathrm{AF}$ & BFT & $\mathrm{AF} \times \mathrm{BFT}$ \\
\hline \multicolumn{9}{|l|}{ FSH $\left(\mathrm{ng} \mathrm{mL} \mathrm{m}^{-1}\right)$} \\
\hline Post farrowing & 2.05 & 2.10 & 2.07 & 2.12 & 0.05 & 0.734 & 0.420 & 0.941 \\
\hline Weaning & 3.08 & 3.13 & 3.11 & 3.18 & 0.04 & 0.547 & 0.284 & 0.906 \\
\hline \multicolumn{9}{|l|}{ LH $\left(\mathrm{ng} \mathrm{mL}^{-1}\right)$} \\
\hline Post farrowing & 0.58 & 0.62 & 0.56 & 0.61 & 0.04 & 0.788 & 0.420 & 0.941 \\
\hline Weaning & 0.72 & 0.68 & 0.70 & 0.63 & 0.03 & 0.427 & 0.138 & 0.677 \\
\hline \multicolumn{9}{|l|}{ Cortisol (ng mL ${ }^{-1}$ ) } \\
\hline Gestation (day 90) & 4.59 & 4.56 & 4.58 & 4.52 & 0.18 & 0.911 & 0.863 & 0.955 \\
\hline Post farrowing & 6.27 & 6.13 & 5.95 & 5.98 & 0.12 & 0.171 & 0.752 & 0.624 \\
\hline Weaning & 4.37 & 4.15 & 4.29 & 4.09 & 0.17 & 0.786 & 0.403 & 0.974 \\
\hline \multicolumn{9}{|l|}{ Insulin $\left(\mu \mathrm{IU} \mathrm{mL} \mathrm{L}^{-1}\right)$} \\
\hline Gestation (day 90) & 20.56 & 20.42 & 20.49 & 20.32 & 0.32 & 0.858 & 0.738 & 0.969 \\
\hline Post farrowing & 24.54 & 24.45 & 24.12 & 24.53 & 0.29 & 0.681 & 0.700 & 0.546 \\
\hline Weaning & 17.79 & 17.55 & 17.68 & 17.34 & 0.38 & 0.767 & 0.591 & 0.924 \\
\hline
\end{tabular}

LB ( $<20 \mathrm{~mm})$ - low backfat; HB ( $\geq 20 \mathrm{~mm})$ - high backfat.

FSH - follicle stimulating hormone; LH - luteinizing hormone; SEM - standard error of mean.

Table 5 - Effects of additional feeding (AF) and backfat thickness (BFT) on colostrum and milk composition of sows during summer

\begin{tabular}{|c|c|c|c|c|c|c|c|c|}
\hline \multirow{2}{*}{$\begin{array}{l}\text { Additional feeding } \\
\text { Backfat thickness }\end{array}$} & \multicolumn{2}{|c|}{ Control } & \multicolumn{2}{|c|}{$\mathrm{AF}$} & \multirow[b]{2}{*}{ SEM } & \multicolumn{3}{|c|}{ P-value } \\
\hline & $\begin{array}{c}\text { LB } \\
(\mathrm{n}=12)\end{array}$ & $\begin{array}{c}\text { HB } \\
(n=15)\end{array}$ & $\begin{array}{c}\text { LB } \\
(n=13)\end{array}$ & $\begin{array}{c}\text { HB } \\
(n=14)\end{array}$ & & $\mathrm{AF}$ & BFT & $\mathrm{AF} \times \mathrm{BFT}$ \\
\hline \multicolumn{9}{|l|}{ Colostrum (\%) } \\
\hline Total solid & 24.31 & 25.09 & 24.51 & 24.93 & 0.43 & 0.975 & 0.328 & 0.770 \\
\hline Protein & 15.82 & 16.24 & 16.02 & 16.44 & 0.29 & 0.624 & 0.304 & 0.997 \\
\hline Fat & 5.26 & 5.50 & 5.46 & 5.37 & 0.16 & 0.890 & 0.739 & 0.477 \\
\hline Lactose & 3.24 & 3.39 & 3.26 & 3.36 & 0.07 & 0.978 & 0.190 & 0.808 \\
\hline \multicolumn{9}{|l|}{ Milk (\%) } \\
\hline Total solid & 19.32 & 19.65 & 19.58 & 19.71 & 0.47 & 0.817 & 0.738 & 0.883 \\
\hline Protein & 5.11 & 5.47 & 5.36 & 5.67 & 0.22 & 0.481 & 0.295 & 0.932 \\
\hline Fat & 7.15 & 7.37 & 7.31 & 7.49 & 0.17 & 0.570 & 0.407 & 0.946 \\
\hline Lactose & 5.23 & 5.39 & 5.35 & 5.46 & 0.14 & 0.635 & 0.506 & 0.895 \\
\hline
\end{tabular}

LB ( $<20 \mathrm{~mm})$ - low backfat; HB ( $\geq 20 \mathrm{~mm})$ - high backfat.

SEM - standard error of mean. 
38.9 and $39.4{ }^{\circ} \mathrm{C}$ in gestation and lactation periods, respectively. The rectal temperature of sows in the present study was higher than the temperature reported in the meta-analysis by Lucy and Safranski (2017), in which thermoneutral (below $25^{\circ} \mathrm{C}$ ) and heat-stressed $\left(25\right.$ to $35^{\circ} \mathrm{C}$ ) sows differed in rectal temperature by approximately $0.3{ }^{\circ} \mathrm{C}\left(38.15\right.$ and $38.47^{\circ} \mathrm{C}$ for thermoneutral and heat-stressed sows, respectively) during the last two weeks of gestation. Furthermore, the lactating sows kept in high ambient temperature (above $25^{\circ} \mathrm{C}$ ) showed a $0.5^{\circ} \mathrm{C}$ increase in rectal temperature, from $38.7^{\circ} \mathrm{C}$ in comfort zone to $39.2^{\circ} \mathrm{C}$ during HS (Ribeiro et al., 2018). Several studies have shown that rectal temperature can be considered as an indicator of the thermoregulation process (Renaudeau and Noblet, 2001; Williams et al., 2013; Lucy and Safranski, 2017). Ribeiro et al. (2018) reviewed 20 recent studies and reported that the thermal comfort zone for lactating sows (ranging from 15 to $25^{\circ} \mathrm{C}$ ) decreased voluntary feed intake and milk output significantly for each Celsius degree increase in ambient temperature above the thermal comfort temperature.

In the present study, the change in BFT of late gestating sows was affected by AF, which agrees with the results reported by Ren et al. (2017b). Moreover, backfat $(\mathrm{P}<0.01)$ and BW $(\mathrm{P}=0.059)$ gain for sows with higher BFT increased during gestation. Greater backfat gain during gestation also resulted in more backfat and BW loss in HB sows during lactation. Consistent with our results, other authors have also found that higher BW gain during the gestation period increased BW loss during lactation (Amdi et al., 2013; Tummaruk et al., 2014; Ren et al., 2017a,b). Increased BFT for sows in the AF group during the gestation period resulted in greater initial litter weight, which may show the positive energy balance of sows to maintain foetal requirements. This might explain why sows in AF treatment had greater initial litter weight (14.15 kg) compared with the control group (13.19 kg). Moreover, the greater changes in fat reserves of sows between late pregnancy and late lactation improve the milk production, resulting in a greater growth performance of piglets (Kim et al., 2010). Biensen et al. (1998) concluded that the amount of feeding during the late gestation is a major determinant of increased foetal growth and foetal carcass fat content. It is well established that the reproductive performance of sows depends on BFT and body conditions during late gestation and early lactation (Houde et al., 2010; Tummaruk et al., 2014). Additionally, BFT and BFT loss at weaning largely rely on ADFI, feeding patterns, and milk production (Maes et al., 2004).

In our study, there were no effects of AF on ADFI in lactating sows during the summer season. In contrast, Ren et al. (2017b) observed that lactation ADFI tended to increase linearly with the increase of feeding levels during gestation. However, sows with higher BFT showed a tendency for lower ADFI $(P=0.097)$. The results of the present study agree with a previous study (Revell et al., 1998), which shows that higher levels of body reserves at farrowing have negative effects on ADFI during lactation. The tendency for lower ADFI may be due to the natural reaction of heavier sows in HS, which allow them to use their body reserves and reduce ADFI to decrease overall metabolic heat production.

There were no effects of AF or BFT on the weaning-to-oestrus interval during the summer season. Also, plasma LH did not differ among the treatments. Plasma LH concentrations trigger follicular growth and seem to be a crucial factor to determine weaning-to-oestrus in sows (Costermans et al., 2019). Choi et al. (2017), however, reported that higher nutrient intake during lactation increased plasma concentration of LH at weaning due to improved body energy balance during HS. The insignificant concentration of LH in this study presumably shows that sows in all treatments were almost in a similar reproductive status at weaning.

The greater initial litter weight obtained in this study agrees with reports showing the positive effects of feed intake of sows during late gestation on litter weight (Cromwell et al., 1989; Ren et al., 2017a,b). A possible explanation for our finding is that the efficiency of energy received from the feed is higher than the energy mobilised from body reserves during HS. In contrast to the AF treatment, initial litter weight was not improved in HB sows. However, the number of piglets at birth was not affected by a change in feeding level during gestation. Our result agrees with a study by Amdi et al. (2013), in which there was no correlation between the number of piglets born alive and the amount of feed intake ( $2.5 \mathrm{vs} 3.5 \mathrm{~kg}$ ) during gestation. A meta-analysis on the influence of management factors on gestating 
sows by Douglas et al. (2014) suggested that the optimal feeding level varies between farms because of differences in genotype, environment, and nutrition. The authors indicated that an increase in ADFI during gestation could have a lasting effect on offspring performance during the hot season. However, they emphasised the need for further investigations, as overfeeding during gestation has to be avoided due to the detrimental effects on BW and reproductive performance of sows. Interestingly, the result of this study showed that the uniformity of piglets was increased in AF sows. Dwyer et al. (1994) also observed that extra feeding during gestation stimulates uniform foetal and muscle fibre growth, reducing the distribution of piglet $\mathrm{BW}$ at farrowing. The results of the current study suggest that during HS, foetal weight and uniformity could be improved to some extent by increasing the feed intake of sows during the last two weeks of gestation regardless of their BFT.

Though the lactation BW loss of sows in AF treatment decreased with the increase in gestation feeding level, the weight of piglets at weaning tended to increase. However, the increased body reserves in gestating sows in AF treatment were not employed during the lactation period to support the energy requirements of piglets, because the change in BFT during the lactation period was not affected by AF treatment. This was not confirmed in the study conducted by Ren et al. (2017b), who reported that a high amount of BFT at farrowing in sows given additional feed during gestation resulted in greater BFT loss during lactation. However, the insignificant difference in final litter weight at weaning found in the study by Ren et al. (2017b) was similar to the result of the current study. Therefore, the insignificant difference in final litter weight at weaning can be explained by the fact that all lactating sows were almost similarly under the influence of HS regardless of BW and BFT.

It has been reported that the number of live piglets weaned is related to the BFT loss (Maes et al., 2004). Moreover, fewer piglets are weaned per litter due to the lower BFT of sows (McKay, 1993). However, in the present study, no effects of BFT on litter size, piglets weaned, and piglet performance were observed during the summer season.

Our results showed that during the summer season, there were no effects of AF on blood glucose, triglyceride, and urea nitrogen at post-farrowing and weaning. Blood glucose, triglyceride, and urea nitrogen levels increased largely through higher ADFI and protein digestion (Heo et al., 2008), which was not observed in our study. However, according to Choi et al. (2018), there is no difference in blood glucose and triglyceride levels of the heat-stressed sows at weaning when sows have different BFT at farrowing ( $<20 \mathrm{vs} \geq 20 \mathrm{~mm}$ ). Moreover, in the present study, extra feeding or different BFT had no significant effect on insulin, FSH, or LH profiles in lactating sows during the summer season. Our results agree with those of Ren et al. (2017a), which indicate that feeding levels during gestation have no effects on insulin concentration. In agreement, Choi et al. (2018) showed that sows with different BFT at farrowing have similar FSH, LH, and insulin levels at weaning.

During the summer season, AF had no effects on milk and colostrum production and composition. The literature reported that daily feed intake affects the gross milk composition (Nyachoti et al., 2006). In addition, HS has a direct effect on milk production and milk composition in lactating sows (Renaudeau and Noblet, 2001). Our results are in contrast with those of Nyachoti et al. (2006), who showed an effect of higher feed intake on milk composition. The difference between our study and earlier studies might be associated to HS.

\section{Conclusions}

Additional feeding ( $400 \mathrm{~g}$ ) during the last two weeks of the gestation period of sows exposed to elevated ambient temperature increases initial litter weight and decreases body weight loss during lactation and has a positive effect on the uniformity of newborn piglets. Furthermore, sows with higher backfat thickness at late gestation lose more weight during farrowing and lactation. However, the final litter weight, weaning-to-oestrus interval, and circulating LH and FSH as reproductive hormones are not affected at weaning. 


\section{Acknowledgments}

This work was carried out with the support of Cooperative Research Program for Agriculture Science and Technology Development (Project No. 01160302), Rural Development Administration, Republic of Korea. The authors are thankful to the Institute of Animal Resources, Kangwon National University, Chuncheon, Republic of Korea, for providing the technical facilities to conduct this experiment.

\section{References}

Amdi, C.; Giblin L.; Hennessy, A. A.; Ryan, T.; Stanton, C.; Stickland, N. C. and Lawlor, P. G. 2013. Feed allowance and maternal backfat levels during gestation influence maternal cortisol levels, milk fat composition and offspring growth. Journal of Nutritional Science 2:1-10. https://doi.org/10.1017/jns.2012.20

Biensen, N. J.; Wilson, M. E. and Ford, S. P. 1998. The impact of either a Meishan or Yorkshire uterus on Meishan or Yorkshire fetal and placental development to days 70, 90, and 110 of gestation. Journal of Animal Science 76:2169-2176.

Cerisuelo, A.; Baucells, M. D.; Gasa, J.; Coma, J.; Carrión, D.; Chapinal, N. and Sala, R. 2009. Increased sow nutrition during midgestation affects muscle fiber development and meat quality, with no consequences on growth performance. Journal of Animal Science 87:729-739. https://doi.org/10.2527/jas.2007-0677

Choi, Y.; Hosseindoust, A.; Shim, Y.; Kim, M.; Kumar, A.; Oh, S.; Kim, Y. and Chae, B. J. 2017. Evaluation of high nutrient diets on litter performance of heat-stressed lactating sows. Asian-Australasian Journal of Animal Sciences 30:1598-1604. https://doi.org/10.5713/ajas.17.0398

Choi, Y.; Hosseindoust, A.; Kim, J.; Lee, S.; Kim, M.; Kumar, A.; Kim, K.; Kim, Y. H. and Chae, B. J. 2018. An overview of hourly rhythm of demand-feeding pattern by a controlled feeding system on productive performance of lactating sows during summer. Italian Journal of Animal Science 17:1001-1009. https://doi.org/10.1080/1828051X.2018.1438214

Costermans, N. G. J.; Teerds, K. J.; Keijer, J.; Knol, E. F.; Koopmanschap, R. E.; Kemp, B. and Soede, N. M. 2019. Follicular development of sows at weaning in relation to estimated breeding value for within-litter variation in piglet birth weight. Animal 13:554-563. https://doi.org/10.1017/S1751731118001684

Cromwell, G. L.; Hall, D. D.; Clawson, A. J.; Combs, G. E.; Knabe, D. A.; Maxwell, C. V.; Noland, P. R.; Orr, D. E. and Prince, T. J. 1989. Effects of additional feed during late gestation on reproductive performance of sows: A cooperative study. Journal of Animal Science 67:3-14. https://doi.org/10.2527/jas1989.6713

De Rensis, F.; Gherpelli, M.; Superchi, P. and Kirkwood, R. N. 2005. Relationships between backfat depth and plasma leptin during lactation and sow reproductive performance after weaning. Animal Reproduction Science 90:95-100. https://doi.org/10.1016/j.anireprosci.2005.01.017

Douglas, S. L.; Szyszka, O.; Stoddart, K.; Edwards, S. A. and Kyriazakis, I. 2014. A meta-analysis to identify animal and management factors influencing gestating sow efficiency. Journal of Animal Science 92:5716-5726. https://doi.org/10.2527/ jas.2014-7986

Dourmad, J. Y.; Etienne, M. and Noblet, J. 2001. Measuring backfat depth in sows to optimize feeding strategy. INRA Production Animal 14:41-50.

Dwyer, C. M.; Stickland, N. C. and Fletcher, J. M. 1994. The influence of maternal nutrition on muscle fiber number development in the porcine fetus and on subsequent postnatal growth. Journal of Animal Science 72:911-917. https://doi.org/10.2527/1994.724911x

Heo, S.; Yang, Y. X.; Jin, Z.; Park, M. S.; Yang, B. K. and Chae, B. J. 2008. Effects of dietary energy and lysine intake during late gestation and lactation on blood metabolites, hormones, milk compositions and reproductive performance in primiparous sows. Canadian Journal of Animal Science 88:247-255. https://doi.org/10.4141/CJAS07060

Houde, A. A.; Méthot, S.; Murphy, B. D.; Bordignon, V. and Pali, M. F. 2010. Relationships between backfat thickness and reproductive efficiency of sows: A two-year trial involving two commercial herds fixing backfat thickness at breeding. Canadian Journal of Animal Science 90:429-436. https://doi.org/10.4141/CJAS09115

Kim, S. W. 2010. Recent advances in sow nutrition. Revista Brasileira de Zootecnia 39:303-310. https://doi.org/10.1590/ S1516-35982010001300033

Lucy, M. C. and Safranski, T. J. 2017. Heat stress in pregnant sows: thermal responses and subsequent performance of sows and their offspring. Molecular Reproduction and Development 84:946-956. https://doi.org/10.1002/mrd.22844

Maes, D. G. D.; Janssens, G. P. J.; Delputte, P.; Lammertyn, A. and de Kruif, A. 2004. Back fat measurements in sows from three commercial pig herds: relationship with reproductive efficiency and correlation with visual body condition scores. Livestock Production Science 91:57-67. https://doi.org/10.1016/j.livprodsci.2004.06.015

McKay, R. M. 1993. Preweaning losses of piglets as a result of index selection for reduced backfat thickness and increased growth rate. Canadian Journal of Animal Science 73:437-442. https://doi.org/10.4141/cjas93-046 
NRC - National Research Council. 2012. Nutrient requirements of swine. 11th ed. Natl. Acad. Press, Washington, DC.

Nyachoti, C. M.; Sands, J. S.; Connor, M. L. and Adeola, O. 2006. Effect of supplementing phytase to corn- or wheat-based gestation and lactation diets on nutrient digestibility and sow and litter performance. Canadian Journal of Animal Science 86:501-510. https://doi.org/10.4141/A04-500

Revell, D. K.; Williams, I. H.; Mullan, B. P.; Ranford, J. L. and Smits, R. J. 1998. Body composition at farrowing and nutrition during lactation affect the performance of primiparous sows: I. Voluntary feed intake, weight loss, and plasma metabolites. Journal of Animal Science 76:1729-1737. https://doi.org/10.2527/1998.7671729x

Renaudeau, D. and Noblet, J. 2001. Effects of exposure to high ambient temperature and dietary protein level on sow milk production and performance of piglets. Journal of Animal Science 79:1540-1548. https://doi.org/10.2527/2001.7961540x

Ren, P.; Yang, X.; Cui, S.; Kim, J.; Menon, D.; Pangeni, D.; Manu, H.; Tekeste, A. and Baidoo, S. K. 2017a. Effects of different feeding levels during three short periods of gestation on gilt and litter performance, nutrient digestibility, and energy homeostasis. Journal of Animal Science 95:77-78. https://doi.org/10.2527/asasmw.2017.12.164

Ren, P.; Yang, X. J.; Kim, J. S.; Menon, D. and Baidoo, S. K. 2017b. Effect of different feeding levels during three short periods of gestation on sow and litter performance over two reproductive cycles. Animal Reproduction Science 177:42-55. https://doi.org/10.1016/j.anireprosci.2016.12.005

Ribeiro, B. P. V. B.; Lanferdini, E.; Palencia, J. Y. P.; Lemes, M. A. G.; de Abreu, M. L. T.; Cantarelli, V. S. and Ferreira, R. A. 2018. Heat negatively affects lactating swine: A meta-analysis. Journal of Thermal Biology 74:325-330. https://doi. org/10.1016/j.jtherbio.2018.04.015

Tummaruk, P.; Sumransap, P. and Jiebna, N. 2014. Fat and whey supplementation influence milk composition, backfat loss, and reproductive performance in lactating sows. Tropical Animal Health and Production 46:753-758. https://doi. org/10.1007/s11250-014-0559-8

Weldon, W. C.; Thulin, A. J.; MacDougald, O. A.; Johnston, L. J.; Miller, E. R. and Tucker, H. A. 1991. Effects of increased dietary energy and protein during late gestation on mammary development in gilts. Journal of Animal Science 69:194-200.

Williams, A. M.; Safranski, T. J.; Spiers, D. E.; Eichen, P. A.; Coate, E. A. and Lucy, M. C. 2013. Effects of a controlled heat stress during late gestation, lactation, and after weaning on thermoregulation, metabolism, and reproduction of primiparous sows. Journal of Animal Science 91:2700-2714. https://doi.org/10.2527/jas.2012-6055 